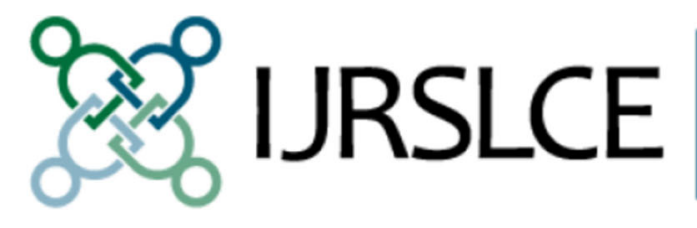

International Journal

for Research on

Service-Learning \&

Community Engagement

\title{
Civic Activity and Well-Being Among First-Year College Students
}

\author{
Nicole Nicotera \\ Sarah Brewer \\ Christopher Veeh
}

This article was originally published at:

https://journals.sfu.ca/iarslce/index.php/journal/article/view/125/77

Recommended Citation

Nicotera, N., Brewer, S., \& Veeh C. (2015). Civic activity and well-being among first-year college students. International Journal of Research on Service-Learning and Community Engagement, 3(1), Article 20. 


\title{
Civic Activity and Well-Being Among First-Year College Students
}

\author{
Nicole Nicotera \\ University of Denver \\ Sarah Brewer \\ University of Colorado Denver \\ Christopher Veeh \\ Washington University in St. Louis
}

\begin{abstract}
Institutions of higher education face the challenge of fostering academic success and well-being among students at a time when depression and substance abuse are on the rise within undergraduate populations. Evidence suggests that service-learning and community service promote undergraduate well-being in relation to substance use and psychological health. The study discussed in this article examined the association between civic activity and several aspects of well-being as it relates specifically to young adults during the first year of college. Results suggest that engaging in civic activities during the high school years or during the first year of college may serve to promote different aspects of well-being among first-year undergraduate students.
\end{abstract}

Keywords: civic engagement, community engagement, college efficacy, flourishing, undergraduate students, well-being, alcohol problems

Institutions of higher education face the challenge of fostering academic success and well-being among students at a time when depression and substance abuse are on the rise within undergraduate populations (Swaner, 2007). In a survey administered by the American College Health Association regarding campus health issues, $17 \%$ of students reported feeling depressed, $13.2 \%$ felt anxious or stressed, and $8 \%$ reported experiencing seasonal affective disorder (Silverman, 2009). The Healthy Minds Study, which reports on a probability sample of 2,800 college students, found that $51 \%$ of participating undergraduates disclosed that they had engaged in binge drinking during previous two weeks (Cranford, Eisenberg, \& Serras, 2009). Other forms of substance abuse are also prevalent among undergraduates, including illicit use of prescription drugs such as pain medications, stimulant medications, and anxiety medications (McCabe, Teter, \& Boyd, 2006).

Offering opportunities for students to take part in civic-oriented curricular and extracurricular experiences may assist in ameliorating some of these challenges. In fact, evidence suggests that servicelearning and community service foster undergraduate well-being in relation to substance use and psychological health (Astin, 1993; Fenzel, 2005). For example, participation in civic engagement has been associated with resistance to anti-social behavior, substance abuse, and disengagement from school (Finn \& Checkoway, 1998; Fogal, 2004; Kelly, 2009). The relationship between civic engagement and well-being among young people has also been documented for areas such as academic development, 
critical thinking, and life skills (Astin \& Sax, 1998; Batchelder \& Root, 1994; Eyler \& Giles, 1999; Gray et al., 1996). Additionally, the likelihood of young people effectively navigating critical life transitions and civic participation as adults increases when they have opportunities to engage in meaningful civic action (Kelly, 2009; Michelsen, Zaff, \& Hair, 2002).

These studies suggest that civic engagement may serve as a means for advancing aspects of wellbeing for young people. Moreover, the percentage of undergraduate students who anticipate that they will engage in some form of civic activity as part of their college experience has nearly doubled (from $17 \%$ to 34\%) between 1990 and 2011 (Hurtado \& DeAngelo, 2012). This combination suggests a potential "winwin" opportunity for both students and institutions of higher education. That is, students win when their expectations to participate in civic activity are met, while colleges and universities win because, as the evidence implies, civic engagement is beginning to be associated with the well-being of students (Astin \& Sax, 1998; Avalos, Sax, \& Astin, 1999; Eccles \& Barbar, 1999; Lerner, 2004). This win-win opportunity could address the concern that youth become less involved in their communities after they complete high school and enter college. That is, even though students anticipate that they will participate in community engagement during college, Andolina and colleagues (2003) report that a greater preponderance of high school students than college students participate in community engagement, further noting that $60 \%$ of college students do not take part in community engagement (Andolina, Jenkins, Zukin, \& Keeter, 2003). Other scholars have echoed this observation, noting that $81 \%$ of students entering college reported that they completed community service during high school but that only $24 \%$ indicated there was a "very good chance" they would do so in college (Vogelgesang, Ikeda, Gilmartin, \& Keup, 2002).

The study highlighted in this article further examined the relationship between civic activity and wellbeing among young adults, specifically within a context of self-reported civic engagement that occurred both prior to college as well as during their first year as undergraduate students.

\section{Literature Review}

As noted earlier, studies reveal that engagement in civic activities is related to positive outcomes among young people. The following review of the literature describes research on the association between different types of engagement (e.g., community service and community service-learning) and well-being outcomes. We also provide a succinct discussion of factors that may influence an individual's inclination to become involved in civic activities.

\section{Community Engagement}

Student community engagement has come to encompass a broad spectrum of student participation in activities that impact community and provide opportunities for reciprocal learning through service and activism (Furco, 1996; Sigmon, 1979). In their seminal description of the civic-minded graduate, Bringle and Steinberg (2010) outlined the goals of higher education in developing educated persons with the ability and passion to pursue the common good. Their description emphasized that civically minded college graduates had opportunities during college to develop the skills, knowledge, and attitudes relevant to civic action. While few universities have explicitly articulated goals of producing civic-minded graduates, most now encourage community engagement, service-learning, or civic participation as part of the engaged college experience. These forms of engagement serve to build student preparation in the areas outlined by Bringle and Steinberg (2011), such as knowledge of social issues, diversity skills, selfefficacy, and civic behaviors. Terry and Bohnenberger (2004) described student community engagement activities as falling along a continuum comprising three types of engaged participation, including community service (CS), community exploration and skill-building (CES), and community action (CA). Each of these types of engagement offers participating students the opportunity to develop a unique set of skills or learning related to civic action (see Appendix for more details). 


\section{Well-Being in College Students}

Recent studies have revealed a particular interest among researchers in describing and measuring aspects of well-being in youth and college-aged populations. The important work of Andrews and Robinson (1991) around subjective well-being produced what they called a "bottom line" or global measure of wellbeing assessing overall happiness and life satisfaction (p. 61). Their work served as a precursor to more recent literature describing various measures of well-being including social, psychosocial, and emotional well-being. Social well-being has been defined as an individual's sense of belonging to a community and value to society (Keyes, 2006a, 2006b, 2009). Checkoway (2011), in a publication of the Association of American Colleges and Universities (AAC\&U), emphasized flourishing when he stated that "“psychosocial well-being' [refers to characteristics of positive mental health measured] by purpose in life, supportive social relationships, feelings of efficacy and optimism about the future" (p. 8). Brown (2008) suggested that well-being encompasses health, cognitive capacity, academic facility, and social emotional functioning. Other aspects of well-being that have been examined include concepts of college self-efficacy (Solberg, O’Brien, Villareal, Kennel, \& Davis, 1993), healthy behaviors related to alcohol (Maddocka, Laforgeb, Rossib, \& O'Hare, 2001), tobacco use, substance use (Degenhardt \& Hall, 2001), exercise (Penedo \& Dann, 2005), and stress reduction (Lazarus, 1984). While all of these areas relate to the overall construct of well-being, each represents only one aspect of the broader construct of well-being.

\section{Student Engagement and Well-Being}

Scholars of various disciplines have espoused the connection between well-being and civic engagement. For example, positive youth development (PYD) scholar Richard Lerner (2004) described thriving young people as those "whose senses of self involve a combined moral and civic commitment to contributing to society ... [and who are] ... on journeys that involve productive civic engagement and valued contributions to other people and to the institutions of their communities" (pp. 4-5). Similarly, social psychologist Corey Keyes stated that "one of the major ingredients of flourishing [is] reaching out and engaging with others in one's environment" and that well-being has a social component that includes social contribution (Keyes \& Haidt, 2003, p.7). In this section, we review some of the research that supports this connection between well-being and civic engagement.

The studies we reviewed measured aspects of well-being using various self-report indicators that included: alcohol use, social support, depressive symptoms, stress, grade point average (GPA) and grades, academic inattention (e.g., skipping class, tardiness, cheating), civic attitudes, and leadership. The research has explored the relationships between types of engagement and these various aspects of wellbeing. For instance, a number of studies examined the link between community service and well-being (Astin \& Sax, 1998; Avalos, Sax, \& Astin, 1999; Eccles \& Barbar, 1999). Eccles and Barber (1999) reported that participation in community service or prosocial activities, such as serving at a food bank or visiting older adults in nursing homes, is related to reduced risky behaviors, stronger academic performance, and full-time college enrollment. Moreover, undergraduates who performed community service (e.g., in elementary schools, hospitals, community centers) gained in the areas of academics, attitudes consistent with civic responsibility, self-reported capacity for leadership, social confidence, and critical thinking (Astin \& Sax, 1998).

There is also a significant body of literature examining how community service-learning influences well-being (Conway, Amel, \& Gerwien, 2009; Knapp, Fisher, \& Levesque-Bristol, 2010; Low, 2011; Reed, Jernstedt, Hawley, Reber, \& DuBois, 2005; Weiler, Haddock, Zimmerman, Krafchick, Henry, \& Rudisill, 2013; Yorio \& Ye, 2012). Conway, Amel, and Gerwien's (2009) meta-analysis, for example, indicated that community service-learning has a moderate effect on academic outcomes (e.g., GPA, motivation, knowledge) and small effects on both personal outcomes (e.g., moral development, selfefficacy, self-esteem) and social outcomes (e.g., social interaction skills, views on diversity). Another study indicated that undergraduate student participation in service-learning courses is associated with positive outcomes for civic attitudes, self-esteem, and interpersonal and problem-solving skills (Weiler et al., 2013). Low's (2011) study of first-year college students provides evidence that community 
engagement in undergraduates is associated with reduced depression scores and lower alcohol consumption.

Other studies have examined the relationship between well-being and participation in a combination of civic-oriented activities and other pro-social opportunities such as attending religious services, socializing with friends, employment and sports (Bowman, Brandenberger, Lapsley, Hill, \& Quaranto, 2010; Busseri et al., 2011; Finlay, Ram, Maggs, \& Caldwell, 2012). For instance, engaging in community service and spiritual, academic, or work activities is associated with lower alcohol consumption (Finlay et al., 2012). Brower (2010) reported that students who participated in living-learning communities demonstrated increased academic and leadership outcomes. Similarly, Busseri et al. (2011) examined well-being outcomes and participation in a combination of activities (e.g., community service, political action, faith-based groups, and nonacademic clubs) and found a relationship to positive outcomes such as psychosocial health and academic capacity. Studies have also found that participation in civic-oriented experiences during high school as well as during college were positively associated with psychosocial health and academic capacity (Busseri et al., 2011). Finally, being active in a combination of servicelearning and community service was found to have extended effects on aspects of future well-being such as finding a purpose in life, personal growth, and life satisfaction (Bowman et al., 2010).

\section{Personal and Familial Influence on Civic Engagement}

Since young people do not arrive at their proclivity for engagement in a vacuum, we also reviewed studies that examined factors influencing individuals' civic engagement such as exposure to civic context via interactions with peers, parental role-modeling, and cultural factors, or exposure to a civic context through discussing political issues with parents, participating in extracurricular activities other than sports, and/or residing in a civically responsive neighborhood (Jones \& Hill, 2003; Kahne \& Sporte, 2008; Kelly, 2009; Zaff, Malanchuk, \& Eccles, 2008). For example, Kelly's (2009) research supported the hypothesis that young people's perceptions of their parent's civic activity influences their own civic engagement. Findings from Jones and Hill's (2003) qualitative study expanded on this by suggesting that young people's engagement is not only influenced by familial role models but also by faith-based convictions, having peers who engage in service, and by personal experiences of having received service and wanting to "give back" to the community (p. 530).

\section{The Current Study}

Our study focused specifically on the well-being outcomes for first-year undergraduate students who

participated in a range of civic experiences that included community service, service-learning, and community action, as well as those students who did not take advantage of civic engagement opportunities. The mid-size, research-intensive university these students attended offers a range of civicoriented curricular and extracurricular activities that are open to all first-year students. These activities include: (a) community service activities such as tutoring, mentoring, participating in service-learning classes like first-year seminars with a service-learning component, or engaging in Greek life philanthropy; (b) participation in institutes for emerging leaders or joining a living-learning community; and (c) community action opportunities such as off-campus school-based community organizing or serving as a peer health educator (see Appendix). Similar to other studies, we focused on aspects of well-being rather than assessing it as a whole construct. In our study, the variables of interest for well-being included measures of college alcohol problems (Maddocka et al., 2001), flourishing (Keyes, 2006a, 2006b), and college self-efficacy (Solberg et al., 1993).

We examined the following research questions:

(1) Does participation in civic-oriented activities influence the psychosocial and academic well-being of first-year undergraduate students?

(2) What is the relative influence of a student's family, faith orientation, and high school levels of civics (i.e., moral development, civic mindedness and civic activity) on student efficacy, flourishing, and alcohol problems at the end of the first-year of college? 
In order to address question two, we hypothesized the model in Figure 1, which suggests an association with the exogenous variables of faith and parent civic-oriented acts and measures of precollegiate civic engagement, which is then associated with aspects of undergraduate well-being at the end of the first academic year.

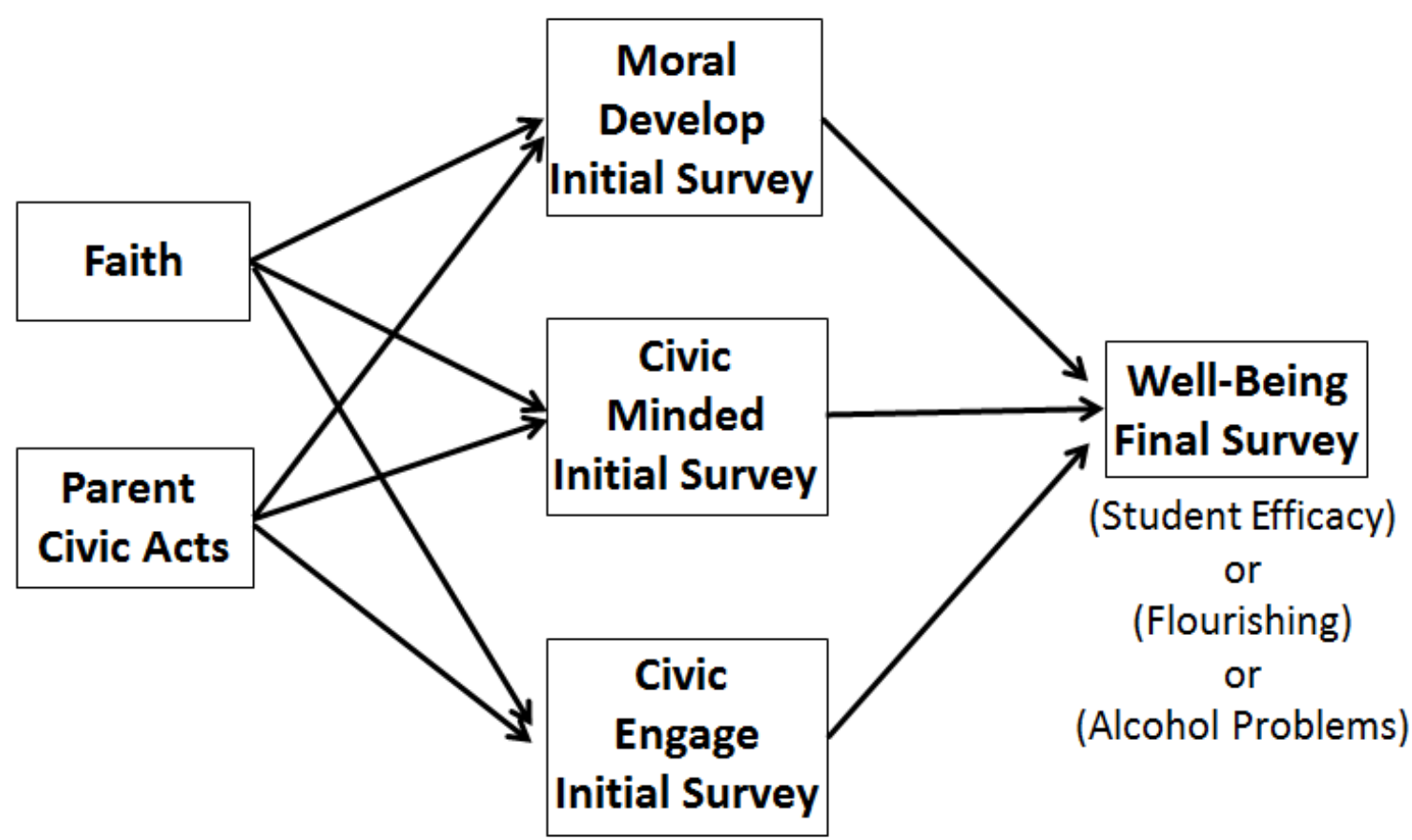

Figure 1. Hypothesized model.

\section{Participants}

\section{Methods}

Prior to the beginning of the fall term in 2011, all incoming first-year undergraduate students $(N=1,274)$ at a private research university located in the Mountain West region of the United States, were invited to participate in the study. All students registered to enroll as first-year students were eligible to participate in the study. Students were invited, via emails from offices of admissions and student advising and from students' first-year orientation faculty, to take an initial (baseline) survey from July through September of 2011. Students who completed the initial survey were contacted again during the spring of 2012 and invited to complete a final survey. Email invitations again came from multiple sources emphasizing the importance of the survey. Of the 1,247 students invited to take the initial survey, a total of $454(36.4 \%)$ responded, and $347(27.8 \%)$ completed the final survey. A total of 225 students (see Table 1) completed both the initial and final surveys; thus, the retention rate was $64.84 \%$. T-tests and chi-square tests were used to examine differences between those who responded to the survey only at the first administration and those who completed the survey at both the first and final administration. There were no significant differences between these two groups regarding the majority of the measures and demographics from the initial survey. However, the group that completed both the initial and final surveys included more males $\left(\chi^{2}(1, N=338)=4.96, p<.05\right)$, more students with lower family incomes $\left(\chi^{2}(5, N=340)=14.63, p<\right.$ $.05)$, higher scores on the civic mindedness scale $(\mathrm{t}(348)=-1.97, p<.05)$, and greater pre-collegiate civic engagement $(\mathrm{t}(339)=-3.07, p<.05)$. 
Table 1. Descriptive Statistics of Demographic Characteristics $(\mathrm{N}=225)$

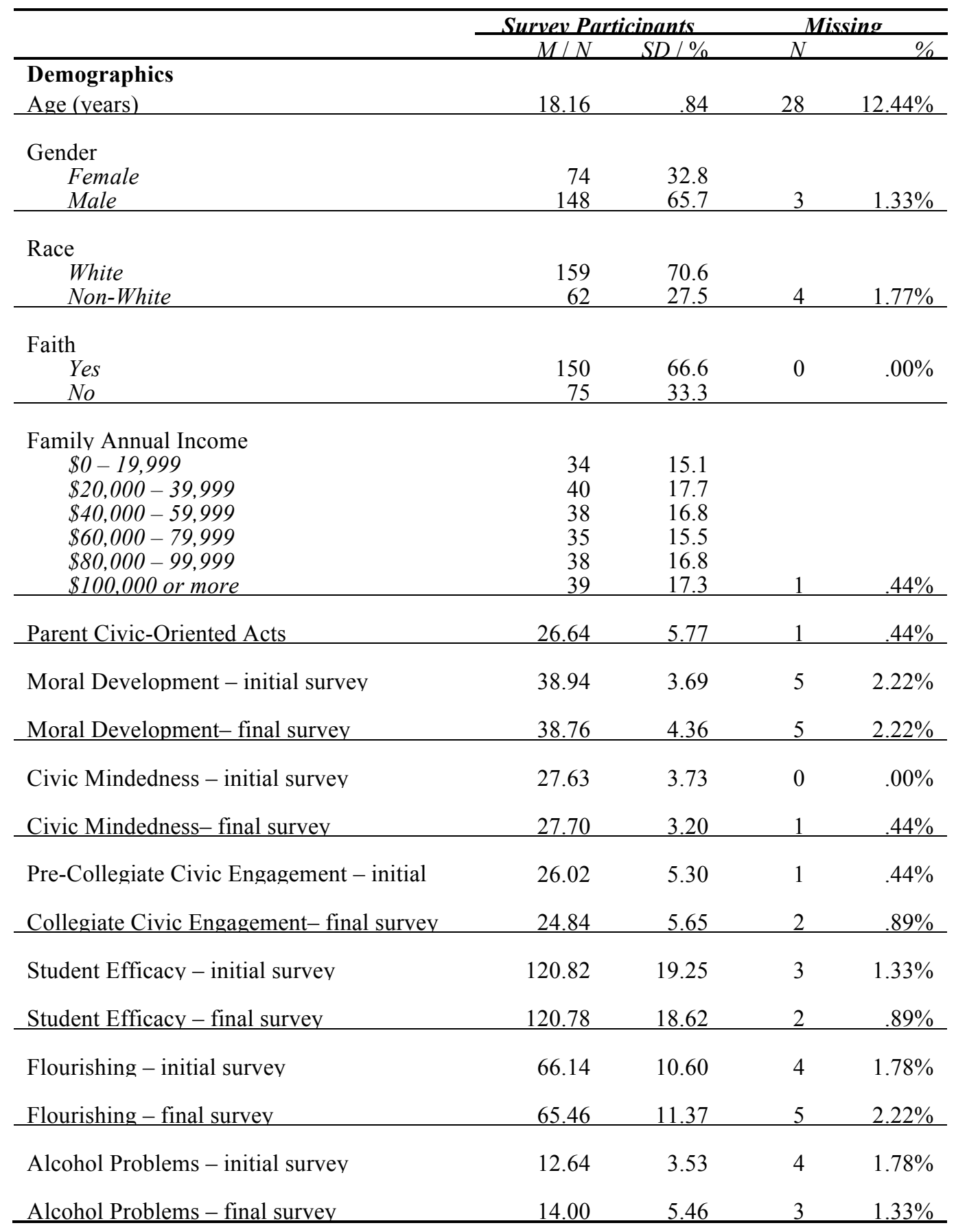

\section{Measures}

The initial survey queried participants about their pre-collegiate (high school) civic and leadership activities and their perception of their parents' civic activity, as well as demographic items (e.g., age, race, gender, sexual orientation, faith tradition, family income, parent occupation). The final survey queried participants about their engagement in first-year civic and leadership activities. In addition, a series of measures of the domains of well-being and civic engagement were administered during both the initial and final data collections: the revised College Alcohol Problems Scale (CAPS-r) (Bringing Theory to 
Practice [BTtoP] Project Team, n.d.; Maddocka et al., 2001), the Mental Health Continuum-Short Form (Keyes, 2006a, 2006b, 2009), the College Self-Efficacy Scale (Solberg et al., 1993), and the civic mindedness and moral development scales (Eyler \& Giles, 1999). Each of these scales is described in the following section in more detail, including the Cronbach's alphas for each survey administration. We also provide available reliability and validity details when reported by the scholars who developed the measures.

\section{Aspects of psychosocial and academic well-being.}

College Alcohol Problems Scale-revised (CAPS-r). The CAPS-r (BTtoP Project Team, n.d.; Maddocka et al., 2001) uses 11 items to measure experiences during the previous month due to drinking (initial $\alpha=$ .844; final $\alpha=.880$ ). These items include: performing poorly on a test, having a hangover, fighting, having sex when one normally would not have, or getting in trouble with parents or authorities. Respondents use a 7-point scale to rate the frequency of their experiences with these issues as a result of drinking, with options including: never, once, twice, 3-5 times, 6-9 times, 10 or more times, or daily.

Mental Health Continuum (MHC)-short form. The MHC-short form instrument, also referred to as flourishing (Keyes, 2006a; 2006b, 2009), contains 14 items on which respondents indicate how they have felt in the previous two weeks - for example, happy, interested in life, belonging to community, confident to express ideas (initial $\alpha=.909$; final $\alpha=.915$ ). Response choices include: never, once or twice, about once a week, 2-3 times a week, almost every day, and every day. This scale was adapted from the Midlife in the United States (MIDUS) study of adults (Keyes \& Magyar-Moe, 2003) and the MHC (Keyes, 2002), and it assesses well-being and flourishing according to three subscales: emotional, psychological, and social well-being. These scales have previously shown strong reliability and validity; the short form of the MHC has shown excellent internal consistency $(\alpha=.80)$ and discriminant validity in adolescents (ages 12-18) and adults in the U.S. (Keyes, 2009).

College self-efficacy. The College Self-Efficacy instrument (Solberg et al., 1993) asks respondents to rate how confident they feel on items such as writing a term paper, keeping up with school work, participating in class discussions, and talking to professors (initial $\alpha=.930$; final $\alpha=.913$ ). Responses to the self-efficacy instrument are rated on a 10-point scale $(1=$ not confident at all, $10=$ extremely confident). The Course Efficacy and Social Efficacy subscales were used in this study as measures of students' academic and psychosocial well-being, respectively. Each of these scales has strong reliability coefficients $(\alpha=.88)$ and also demonstrated convergent and divergent validity with expected measures (Solberg et al., 1993).

\section{Civic engagement measures.}

Civic mindedness. The civic mindedness scale (Eyler \& Giles, 1999) presents seven items on which respondents rate, in comparison to their peers, their capacity to respect the views of others, listen, compromise, work with others, and put others' needs before their own (initial $\alpha=.761$; final $\alpha=.659$ ). Response options include: much worse than most, not as good as most, about the same, better than most, and much better than most.

Moral development. The moral development scale (Eyler \& Giles, 1999) is composed of 10 items on which participants indicate their attitudes about social problems, their impact on solving problems in their community, and their capacity to collaborate with diverse populations (initial $\alpha=.567$; final $\alpha=.676$ ). Respondents are asked to rate their level agreement on a 5-point scale with the following options: strongly disagree, disagree, neither agree or disagree, agree, and strongly agree.

Parent civic-orientated activities. For this study, parent civic-oriented activities (BTtoP Project Team, n.d.) were measured by asking respondents to indicate how often in the previous year their parents engaged in eight different activities such as following the news, voting, community service, and attending religious services (initial $\alpha=.781$ ). Respondents rated their own civic engagement on the same eight activities (initial $\alpha=.694$; final $\alpha=.738$ ). For both parents' and students' own activities, response choices included: not at all, very little, some, quite a bit, and very much. 
College civic activities. During the spring 2012 data collection, students also reported on their firstyear participation in civic-oriented curricular and extracurricular activities or noted no engagement in these activities. The civic-oriented opportunities included: tutoring, mentoring, Greek life philanthropy, serving as a peer health educator, enrolling in a service-learning class such as first-year seminars with a service-learning component, participating in institutes for emerging leaders, off-campus school-based community organizing, or joining a living-learning community. Based on the developmental servicelearning typology described by Terry and Bohnenberger (2004), we delineated these responses into a variable with four categories: no participation, community service (CS), community exploration and skillbuilding (CES), and community action (CA). Community service was defined as short-term service activities without a focus on student learning or reflection (Terry \& Bohnenberger, 2004). Community exploration and skill-building was defined as community engagement experiences with an emphasis on student learning and critical reflection, including service-learning courses (Terry \& Bohnenberger, 2004). Community action was defined as opportunities through which students participated in and created formal, mutually beneficial partnerships with community members and organizations through which both entities participated in learning and critical reflection (Terry \& Bohnenberger, 2004). See the Appendix for a description of the programs included in this typology of campus-community engagement opportunities as well as our reasoning for this categorization based on program goals and structure.

\section{Procedures}

Email invitations were sent to each student during the three weeks prior to arrival on campus for orientation and the start of the academic year. The admissions office sent the first email invitation, then a second email invitation was sent from the academic advising office, and a third email was sent from one of the study investigators. A fourth round of invitations was sent to smaller student-orientation groups via their orientation leaders just prior to and during the on-campus orientation that takes place for all incoming students in preparation for the start of classes. Researchers made considerable efforts to improve the response rate through personalized invitations and by having invitations come from respected faculty and first-year seminar leaders. Responses to the initial round of the survey were accepted through the first three weeks of classes during the fall term for an open survey period of seven weeks.

At the mid-point of the spring term, invitations to complete the final round of the survey were sent weekly via email over five weeks, and responses were accepted through the end of the academic year. Email invitations to complete the final survey came from study investigators as well as the office of advising. In an effort to retain respondents who had completed the initial surveys, researchers personalized follow-up invitations and made repeat contact with all respondents to the initial survey.

Both rounds of the survey were administered through the online survey platform Qualtrics. Incentives were provided to increase survey response rates; respondents were entered into a drawing to win a tablet, and those who completed both surveys received a gift card to the university bookstore. All study procedures were approved by the university's institutional review board.

\section{Results}

Data from respondents who completed both the initial and final surveys were retained for analysis. Students who completed the initial survey but not the final survey were excluded from our analyses. Analyses included descriptive statistics, one-way analysis of variance (ANOVA), and path analysis. The statistical package SPSS 22.0 was used to conduct the descriptive analysis and ANOVA. LISREL 9.1 was used for the path analysis. Statistical significance of the test statistics and parameter estimates was determined to be at the 0.05 alpha level.

\section{Analysis of Variance}

The ANOVA was used to examine differences in the measures of civic engagement and well-being at the end of the first-year among the categories of students' participation in campus civic engagement 
opportunities, using the service categories identified in Terry and Bohnenberger's (2004) model (i.e., no engagement, CS, or CES-CA). Individuals who engaged in community exploration and skill-building activities only or in community action activities only were combined into a single category for analysis due to small sample sizes in each and similarities in program intents and student learning goals. In order to create mutually exclusive categories, students who indicated participation in more than one type of campus civic engagement opportunity were excluded from the ANOVA analysis. Post-hoc tests were run for significant findings to determine the specific group difference.

The ANOVA found significant mean differences for only the College Alcohol Problems Scale $(\mathrm{F}(2,171)=3.06, p<0.05)$. The ANOVA test for college alcohol problems violated the homogeneity of variance assumption (Levene's $=5.54, p<0.05$; Brown-Forsythe $=3.96, p<0.05$ ), so post-hoc comparisons were completed using Dunnett's T3 test. Post-hoc analysis indicated that the students who participated in CES-CA activities $(M=12.03,95 \%$ CI $[11.28,12.78])$ had significantly lower scores on the CAPS-r than either the students in CS activities ( $M=14.77,95 \%$ CI $[13.49,16.06])$ or students who indicated no participation in the CS, CES, or CA campus activities $(M=14.60,95 \%$ CI $[13.02,16.17])$.

\section{Path Analysis}

Path analysis was used to explore the hypothesized model (see Figure 1), which posited an association between the exogenous variables of faith affiliation and parent civic-oriented acts and measures of precollegiate civics (civic engagement, civic mindedness, moral development), which in turn was associated with several aspects of well-being at the end of the first year of college. Separate path models were run with student efficacy, flourishing, or college alcohol problems as the primary well-being outcome. Total scores from each scale were used as indicators for the constructs within the path model.

Guided by the exploratory focus of the current study, we posited an indirect effects hypothesis because the scholars MacKinnon, Fairchild, and Fritz (2007) and Hayes (2009) recommended relaxing the requirement of a significant direct effect before the testing of indirect effects. The standard definition of mediation (see Baron \& Kenny, 1986) has been criticized for the requirement that a total direct effect of $\mathrm{X}$ to $\mathrm{Y}$ has to exist a priori-within the $\mathrm{X} \rightarrow \mathrm{M} \rightarrow \mathrm{Y}$ sequence of the mediational model - in order to test for indirect effects (Hayes, 2009; MacKinnon, Fairchild, \& Fritz, 2007; Mathieu \& Taylor, 2006. p. 1032). In fact, Fritz and MacKinnon (2007) identified Baron and Kenny's (1986) approach to mediation as having low power in detecting indirect effects; thus, for this exploratory study, we chose an alternative approach with higher statistical power to detect indirect effects. As described by Mathieu and Taylor (2006), indirect effects "are a special form of intervening effect whereby $\mathrm{X}$ and $\mathrm{Y}$ are not related directly," but instead X and Y are related through "significant relationships with a linking mechanism" (p.1039), which is referred to as a "test of joint significance" (Hayes, 2009, p. 410).

Prior to conducting the path analysis, the data were checked for missing values, statistical power, multicollinearity, and multivariate normality. Among variables included in the path analysis, the highest rate of missing data was $2.22 \%$; there were 17 cases $(7.56 \%)$ of incomplete data. All missing data were determined to be missing at random (MAR); therefore, listwise deletion was used in all analyses. With at least 10 cases for each parameter in the path model, adequate power existed to conduct significance testing (Kline, 2011). There were no issues regarding multicollinearity, but multivariate normality was violated because the variables of civic mindedness, student efficacy, and college alcohol problems did not meet the assumption of univariate normality (Kline, 2011). Due to this violation of multivariate normality, diagonally weighted least-squares (DWLS) estimation was used instead of maximum likelihood (Honjo, Tsustumi, Kawachi, \& Nawakami, 2006; Mindrila, 2010). Diagonally weighted leastsquares estimation uses a diagonal weight matrix with robust standard errors and estimates chi-square statistics adjusted for both mean and variance. Within LISREL 9.1, the bootstrapping option with 1,000 resamples of $50 \%$ of the total sample size was used to compute the polychoric correlation matrix and asymptotic covariance matrix used in DWLS estimation.

Model-to-data fit was determined using the chi-square test, root mean square error of approximation (RMSEA), and the comparative fit index (CFI). Adequate model fit is defined as a non-significant chisquare test and goodness-of-fit indices that meet cutoff values of RMSEA $<.06$ and CFI $>.95$ (Hu \& 
Bentler, 1999). Using the tear down procedure (Cohen, Cohen, West, \& Aiken, 2003), we began with the hypothesized model and then systematically removed non-significant paths until adequate model fit was obtained. Because the chi-square statistic from the DWLS estimator cannot be used in chi-square difference tests (Honjo et al., 2006), overall model fit was used within the tear down procedure.

Hypothesized model. While we hypothesized that all three student-level civics variables would function within our model (Figure 1), civic mindedness and moral development fell out of the final models, and pre-collegiate civic engagement remained. The results for each of the three retained models are outlined below.

College self-efficacy model. The first iteration of the hypothesized model (see Figure 1) detailed that the exogenous variables of faith and parent civic-oriented acts were associated with students' precollegiate civic engagement, and then in turn civic engagement measures were associated with college self-efficacy at the end of the first-year. Model-to-data fit was determined to be inadequate $\left(\chi^{2}(5)=\right.$ $70.83, p<.05$; RMSEA $=.15$; CFI $=.47$ ). However, following the tear down procedure (Cohen et al., 2003), non-significant paths were eliminated from the model until adequate overall model fit was obtained. The tear down procedure resulted in the final model diagrammed in Figure 2.

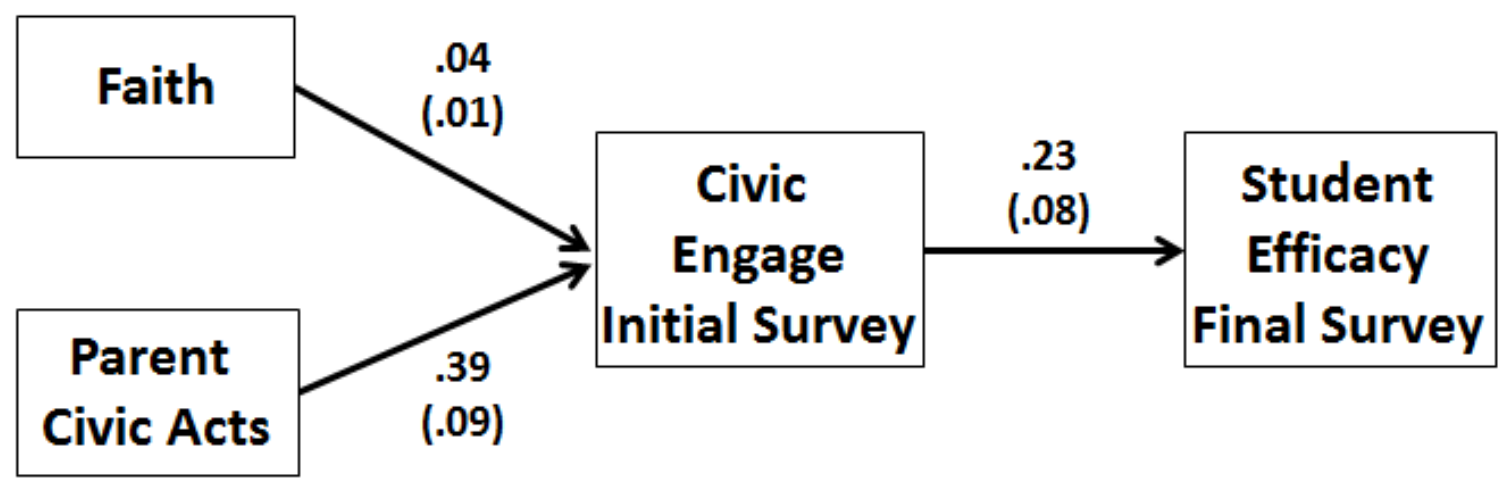

Figure 2. Final student efficacy model with standardized coefficients. Note: Standard error is included in parentheses.

Fit indices for the final model with college self-efficacy demonstrated adequate model-to-data fit $\left(\chi^{2}(2)=2.162, \mathrm{p}=.34\right.$; RMSEA $=.02$; and CFI $\left.=.97\right)$. Standardized path coefficients found statistically significant associations between the exogenous variables of faith $(\beta=0.04)$ and parent civic-oriented acts $(\beta=0.39)$ and students' pre-collegiate civic engagement. In turn, pre-collegiate civic engagement $(\beta=$ 0.23 ) was positively associated with a student's college self-efficacy score at the end of the academic year.

Flourishing model. Path analysis was again used to test the hypothesized model with flourishing as the primary well-being measure. Similar to the college self-efficacy model, model-to-data fit of the flourishing model was inadequate $\left(\chi^{2}(5)=68.60, p<.05\right.$; RMSEA $=.15$; CFI $\left.=.47\right)$. However, the tear down procedure resulted in the final model shown in Figure 3.

Model-to-data fit of the final flourishing model was adequate $\left(\chi^{2}(2)=.947, \mathrm{p}=.63\right.$; RMSEA $=.00$; and CFI $=1.00)$. Standardized path coefficients found statistically significant associations between faith $(\beta=0.04)$ and parent civic-oriented acts $(\beta=0.39)$ and students' pre-collegiate civic engagement. Precollegiate civic engagement $(\beta=0.20)$ was then significantly associated with a student's flourishing score at the end of the first-year. 


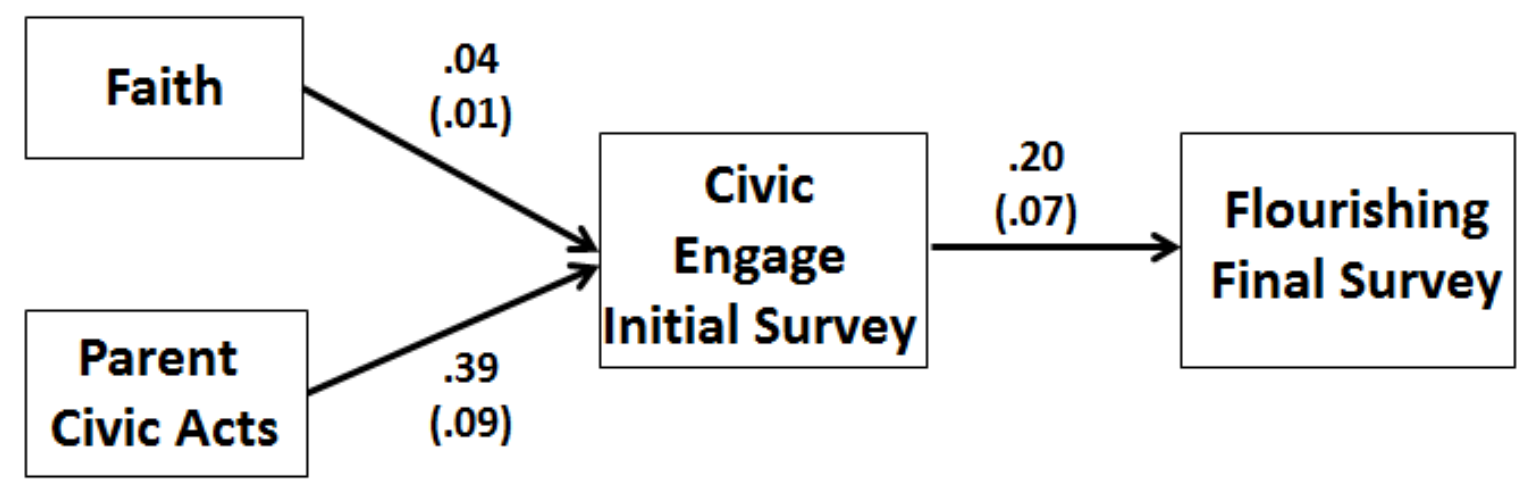

Figure 3. Final flourishing model with standardized coefficients. Note: Standard error is included in parentheses.

College alcohol problems model. The hypothesized model that includes college alcohol problems as a well-being outcome was found to have inadequate model-to-data fit $\left(\chi^{2}(5)=69.04, p<.05\right.$; $\mathrm{RMSEA}=$ .15 ; CFI $=.40$ ). The tear down procedure resulted in a final model for college alcohol problems (see Figure 4), which was similar to those identified for college self-efficacy and flourishing. The final college alcohol problems model evidenced adequate fit $\left(\chi^{2}(2)=.667, p=.7164\right.$; RMSEA $=.05$; and CFI $\left.=1.00\right)$. Standardized path coefficients found statistically significant associations between faith $(\beta=0.04)$ and parent civic-oriented acts $(\beta=0.40)$ and pre-collegiate civic engagement. However, the pre-collegiate civic engagement score was not significantly associated with a student's college alcohol problems at the end of the first year.

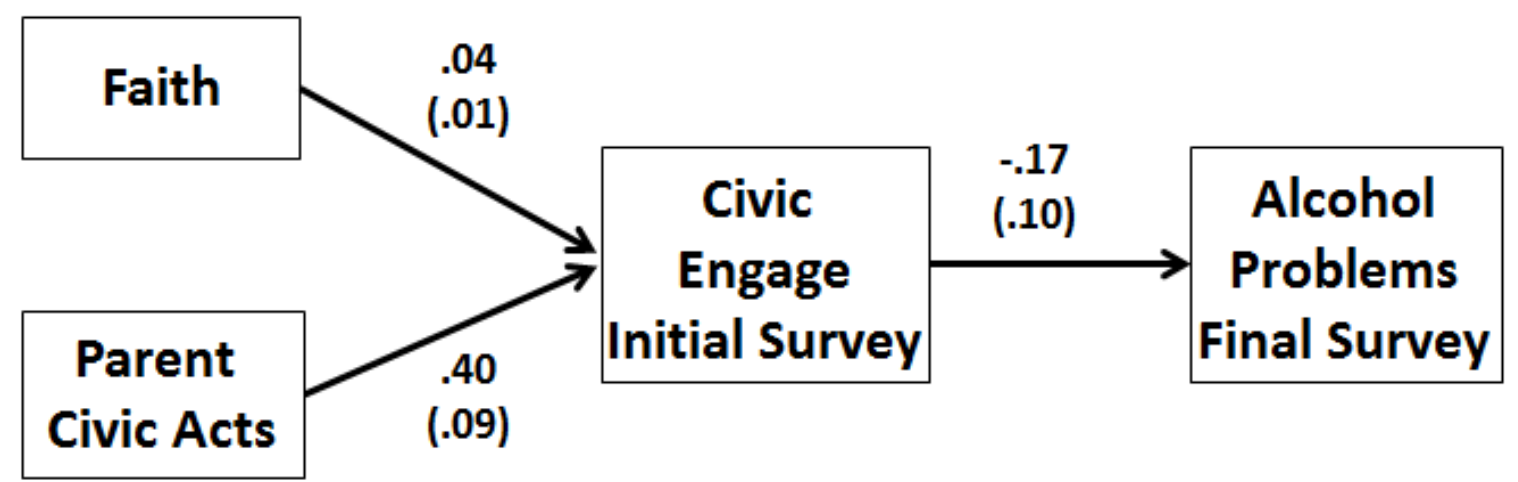

Figure 4. Final alcohol problems model with standardized coefficients. Note: Standard error is included in parentheses.

\section{Discussion}

The purpose of this study was to examine the relationship between first-year undergraduate students' well-being and participation in civic-oriented curricular and extracurricular activities. We also endeavored to untangle the relationships between well-being in the first year of college and parental role modeling of civic behavior, individual faith affiliation, and pre-collegiate civic engagement. Readers are asked to remember that this study was correlational in nature and that our findings do not suggest causal 
relationships. The findings of our ANOVA support our hypothesis that participation in civic-oriented activities during the first year of college is related to psychosocial and academic well-being of first-year undergraduate students. More specifically, students who participated in community exploration and skillbuilding (CES) or community action (CA) were less likely to report college alcohol problems than either the students in community service (CS) activities or students who participated in no campus community engagement opportunities. This suggests that participation in CES or CA activities during the first year of college may decrease a student's likelihood for binge drinking and unhealthy alcohol use among first-year students. For example, participation in a first-year seminar with a service-learning component may be related to fewer alcohol problems for students in the course. This finding aligns with Robert's (2013) study, which found that high school youth who participated in one or more hours of community service per month were less likely to use alcohol. While other studies (Vogelgesang \& Astin, 2000; Vogelgesang et al., 2002) have reported an association between community engagement and other aspects of wellbeing such as academics, interpersonal communication, and leadership skills, our ANOVA did not suggest similar relationships. However, the indicators of well-being used in our research were different from those used in these other studies. Thus, we do not suggest that our findings refute those of these other projects but instead take heart in the fact that this other research suggests that community engagement may promote other aspects of well-being.

Our path analysis confirmed that parental role modeling of civic behavior and students' faith affiliation were associated with pre-collegiate civic engagement. These findings align with studies indicating that parents' civic actions influence their children's civic engagement (Andolina et al., 2003; McIntosh, Hart, \& Youniss, 2007) and with Gibson's (2013) research, which reports that a youth's religious involvement increases the chances that he or she will volunteer. There was no association between these variables and college alcohol problems at the end of students' first year of undergraduate education. This suggests that pre-collegiate experiences of civic engagement, such as following the news, voting, and performing community service, are not associated with lower levels of college alcohol problems. This is not surprising, given the number of changes young people face between the end of high school and the first year of college as they revel in living at a distance from parents and explore risks that may not have previously beckoned due to closer parental scrutiny during the high school years. However, the ANOVA results described earlier suggest that participation in more structured civic engagement opportunities, such as CES and CA programs during the first year of college, is associated with decreased binge drinking and other alcohol problems in first-year students.

Our path models for college self-efficacy and flourishing, however, do suggest that the more distal factors of parental civic role modeling, students' faith affiliation, and pre-collegiate civic engagement offer hope for influencing college self-efficacy and flourishing during the first year of college. It is possible that first-year students who have a civic parental role model and faith connection in mind, as well as a history of civic acts such as reading the newspaper and community service or participating in protests, have a stronger foundation for developing a sense of college self-efficacy and experiencing flourishing in the undergraduate college environment during the first year. Given these associations, we would expect to see students with a history of pre-collegiate civic engagement to have a greater likelihood of student achievement and of increased happiness, belonging, and confidence. However, alcohol abuse will still remain a persistent problem on college campuses.

Civic mindedness (e.g., the capacity to respect the views of others, listen, compromise, and put others' needs before their own) and moral development (e.g., students' belief that social problems are their concern, that they can have an impact on solving problems in their community, and that they have the capacity to collaborate with diverse populations) were excluded from all final models, based on the tear down procedure, in order to obtain adequate model-to-data fit. This suggests that young adults may need assistance in developing the skills of civic mindedness and the ideals of moral development over the course of their higher educational experience. In fact, they may develop these skills and ideals as part of their participation in civic-oriented curricular and extracurricular opportunities such as community service and community service-learning. 


\section{Limitations}

There are important limitations to keep in mind when interpreting this study's findings. First, we caution against generalizing from our findings for three reasons: the absence of probability sampling, the focus on respondents from one institution only, and the fact that during the fall term there were multiple campuswide events focused on the 2012 presidential election, which could have biased the findings compared to students attending universities that did not hold similar civic events during a presidential election year or who entered their undergraduate education during mid-term election years. In addition, our survey completion rates were lower than expected, with an initial survey response rate of $36.4 \%$ and a completion rate of $27.8 \%$. While lower than anticipated, these rates were similar to those found in studies that reported on response rates to online surveys (Cook, Heath, \& Thompson, 2000; Sinclair, O'Toole, Malawaraarachchi, \& Leder, 2010). For example, Cook et al. (2000) found a mean response rate of 34.6\% across surveys used in 39 studies.

In addition, a number of individuals who responded to the initial survey did not complete the final survey at the end of the first year. While this group and the group that completed both surveys were mostly statistically similar, there were some differences between these two groups. The group that completed both surveys included more individuals with lower family income, more males, and higher scores on civic mindedness and pre-collegiate civic engagement than those who completed only the initial survey. However, in spite of these higher scores on civic mindedness and pre-collegiate civic engagement, the sample for this study still included individuals who reported no engagement in any of the civic activities offered during the first year of college.

Moreover, these differences in civic mindedness and pre-collegiate civic engagement may imply an alternative explanation for the associations identified in this study. Specifically, these group differences could extend to unobserved factors, such as personal motivation or the influence of a mentor, that predispose those individuals who completed both surveys to self-select into relationships and social environments that are themselves strongly associated with better outcomes in terms of flourishing, selfefficacy, and alcohol use independent of the factors modeled in this study. Future research into the influence of civic engagement on well-being should make more rigorous attempts to control for these and other possible alternative explanations in order to better understand how universities can effectively promote well-being among first-year undergraduate students.

Other limitations concern the statistical decisions made during analysis. Specifically, we decided to combine the categories of CES and CA activities in the ANOVA to account for small numbers in each. This decision was guided by the assumption that the programs in each category provided similar intents and student learning goals. Finally, some of the participants elected to engage in more than two program types (e.g., CE and CA, or CES and CA, etc.), and these individuals were eliminated from the ANOVA in order to maintain mutually exclusive categories for this analysis. This decision prevented the examination of a possible "stacking effect" among students exposed to multiple types of community engagement opportunities.

\section{Conclusion and Implications}

A young adult's time as a college student is often considered to be an idyllic time of growth and exploration. Yet, these years can also be wrought with the difficulties of coping with stress, learning to manage responsibility, and transitioning into adulthood, and the increased freedom can be accompanied by anxiety and depression. As adolescents and young adults work to build new social networks, there is often social pressure to engage in binge drinking and illicit drug use. Our findings suggest that engaging in civic activities during the first year of college may be associated with aspects of well-being among first-year undergraduate students. This implies a need for higher education faculty and administration to think of civic engagement and well-being programs in conjunction with each other rather than as entirely separate programs with disparate student outcome goals. For example, those who run campus programs related to student problems such as depression and substance abuse may want to join forces with those who administer programs that engage students in civic-oriented opportunities such as service-learning courses and living-learning communities. In addition, the findings suggest that parents and high school 
educators are important factors that appear to play a role in sustaining young people's academic and psychosocial well-being as they enter into the college years.

Since our study was not longitudinal, we cannot infer that civic activity serves as an inoculation against unhealthy habits, only that the aspects of well-being we investigated and civic activity are associated with one another. Nor can we infer causality from our findings, which, again, are correlational in nature. Nonetheless, the findings do support the need for further research into the efficacy of civic engagement as a means for promoting well-being in undergraduate students. College is a time of transformation when young people are poised to develop life habits that can create and sustain well-being beyond the undergraduate years (Ottenritter, 2004). Since habits of civic activity appear to be related to well-being, we encourage our colleagues to join us in future studies to examine this relationship. One of the greatest challenges to examining the relationship between community engagement and well-being is determining whether those who practice healthy behaviors are more inclined to be civically engaged (i.e., does initial well-being lead to civic engagement?) or if community engagement can actually cause or promote well-being. Future studies could address this challenge. For instance, researchers might randomly assign students in a first-year cohort to conditions of community service (CS), community exploration and skill-building (CES), community action (CA), or regular campus life and use mixedmethods data collection and analysis to follow those students longitudinally to assess well-being outcomes. However, this kind of random assignment would pose its own challenges and limitations given the importance of free choice and exploration among college students.

A potentially more feasible longitudinal study might use mixed methods to follow students from the first year, regardless of whether or not they participate in community engagement. This would provide a deeper "story" about the role of self-selection-that is, mixed methods would allow for data collection and analysis that could unpack the processes that occur among undergraduates who choose these different levels of civic engagement or who choose regular campus without community engagement. The qualitative portion of such a mixed-methods study could help to identify whether undergraduates who choose community engagement also happen to choose healthier behaviors such as refraining from alcohol abuse. It would also lead to insights about students who do not choose community engagement as part of their college experience and the kinds of well-being outcomes they report. Understanding this segment of the undergraduate population is imperative given that $60 \%$ of college students do not choose community engagement (Andolina, 2003). For example, understanding this segment of students who do not choose community engagement but exhibit healthy choices may increase our knowledge of other avenues that foster well-being among this population. Such knowledge could lead colleges to further develop and implement these kinds of opportunities in addition to community engagement, thus broadening the means for enhancing the well-being of all students, not just those who choose community engagement. 


\section{Appendix}

\section{Campus-community engagement opportunities as applied to the Terry and Bohnenberger (2004) developmental service learning typology.}

\begin{tabular}{|c|c|c|}
\hline Typology* & Campus community engagement opportunities & Reasoning \\
\hline \multirow{4}{*}{$\begin{array}{l}\text { Community } \\
\text { Service } \\
\text { Programs that } \\
\text { involved a high } \\
\text { degree of service, } \\
\text { but little } \\
\text { structured } \\
\text { learning. }\end{array}$} & $\begin{array}{l}\text { 1. Greek life: Men's and women's organizations } \\
\text { offer opportunities for lifelong friendship, } \\
\text { leadership development, scholarship } \\
\text { enhancement and social interaction. Greek } \\
\text { organizations engage in philanthropy and service. }\end{array}$ & $\begin{array}{l}\text { Greek Life participants under take } \\
\text { philanthropy projects throughout the year } \\
\text { with supervision from student life staff. } \\
\text { No formal or structured learning is linked } \\
\text { to these service activities. }\end{array}$ \\
\hline & $\begin{array}{l}\text { 2. First-year seminars with community service- } \\
\text { learning. The first-year seminar is required for all } \\
\text { first-year students, but they may elect to take it } \\
\text { with or without a service-learning component. }\end{array}$ & $\begin{array}{l}\text { Students participate in service activities } \\
\text { through a semester and engage in some } \\
\text { structured learning or reflection. }\end{array}$ \\
\hline & $\begin{array}{l}\text { 3. Tutoring and Mentoring: Offered as an entry- } \\
\text { point to school-based community service } \\
\text { programs, students tutor or mentor K-12 students } \\
\text { at public schools near the campus. }\end{array}$ & $\begin{array}{l}\text { Students participate in service activities } \\
\text { through a semester and engage in little } \\
\text { structured learning and reflection with } \\
\text { other tutors. }\end{array}$ \\
\hline & $\begin{array}{l}\text { 4. Student Life: Approximately } 20 \text { student } \\
\text { organizations engaged in service work throughout } \\
\text { the academic year. }\end{array}$ & $\begin{array}{l}\text { Students participate in service activities } \\
\text { either regularly or at periodic events and } \\
\text { engage in no structured learning. }\end{array}$ \\
\hline \multirow{3}{*}{$\begin{array}{l}\text { Community } \\
\text { Exploration } \\
\text { \& Skills Training } \\
\text { Programs that } \\
\text { focus on } \\
\text { education from } \\
\text { real-world } \\
\text { activities and } \\
\text { reflection. }\end{array}$} & $\begin{array}{l}\text { 1. Leadership Program: Promotes leadership } \\
\text { through intellectual engagement, personal } \\
\text { development, and service in the community. The } \\
\text { program includes an academic minor. }\end{array}$ & $\begin{array}{l}\text { Students undertake a service requirement } \\
\text { with a chosen local partner organization } \\
\text { during the full academic year and } \\
\text { participate in structured reflection } \\
\text { throughout the academic component of } \\
\text { the program. }\end{array}$ \\
\hline & $\begin{array}{l}\text { 2. Living-Learning Communities (LLC): } \\
\text { Combine academics, residential learning and } \\
\text { community engagement. }\end{array}$ & $\begin{array}{l}\text { Students undertake a service requirement } \\
\text { throughout an academic year and } \\
\text { participate in structured reflection } \\
\text { throughout the academic and living } \\
\text { components of the LLC. }\end{array}$ \\
\hline & $\begin{array}{l}\text { 3. Diversity Leadership Retreat: Brings } \\
\text { students from various social identity backgrounds } \\
\text { together for self-discovery and skills training } \\
\text { related to leadership and diversity. }\end{array}$ & $\begin{array}{l}\text { Students engage in intensive skills- } \\
\text { building and sharing of experiences. }\end{array}$ \\
\hline \multirow{3}{*}{$\begin{array}{l}\text { Community } \\
\text { Action } \\
\text { Programs in } \\
\text { which students } \\
\text { interact with and } \\
\text { upon the } \\
\text { community by } \\
\text { engaging in forms } \\
\text { of civic } \\
\text { engagement such } \\
\text { as petitioning, } \\
\text { community } \\
\text { organizing. }\end{array}$} & $\begin{array}{l}\text { 1. Youth Community Organizing: A youth } \\
\text { civic engagement initiative focused developing } \\
\text { youth citizenship, democracy and public work. } \\
\text { Undergraduate students work with middle and } \\
\text { high school students to foster leadership and } \\
\text { address community issues. }\end{array}$ & $\begin{array}{l}\text { Undergraduates engage in community } \\
\text { change by fostering leadership and } \\
\text { addressing community issues alongside } \\
\mathrm{K}-12 \text { students. Commitment is intensive, } \\
\text { highly-structured and involves reflection, } \\
\text { skills-building and service. }\end{array}$ \\
\hline & $\begin{array}{l}\text { 2. School-Based Civic Engagement: Mutually } \\
\text { beneficial school-university partnerships in which } \\
\text { university students work with K-12 students in } \\
\text { various capacities. }\end{array}$ & $\begin{array}{l}\text { Undergraduates work on community } \\
\text { projects with K-12 students. Commitment } \\
\text { is intensive, highly structured and } \\
\text { involves reflection, skills-building and } \\
\text { service. }\end{array}$ \\
\hline & $\begin{array}{l}\text { 3. Health Peer Educators: A student } \\
\text { organization for peer health education that works } \\
\text { with the campus health center }\end{array}$ & $\begin{array}{l}\text { Participants develop curriculum and } \\
\text { activities for other undergraduates and } \\
\text { engage in community-based action. }\end{array}$ \\
\hline
\end{tabular}

*Note: All typology descriptions from Terry \& Bohnenberger, 2004 


\begin{abstract}
Author Note
Nicole Nicotera, Graduate School of Social Work, University of Denver; Sarah Brewer, Children's Outcomes Research Program, University of Colorado Denver; Christopher Veeh, Brown School, Washington University in St. Louis.

This research was funded by a grant from the Bringing Theory to Practice Project of the Association of American Colleges and Universities.
\end{abstract}

\title{
Correspondence
}

Correspondence regarding this article should be addressed to Nicole Nicotera, Associate Professor, Graduate School of Social Work, University of Denver, Craig Hall, Room 467, 2148 S. High Street, Denver, CO 80208. Phone: (303) 871-2301. E-mail: nicole.nicotera@du.edu

\section{References}

Andolina, M., Jenkins, K., Zukin, C., \& Keeter, S. (2003). Habits of home, lessons from school: Influences on youth civic engagement. PSOnline (April), 275-280. Retrieved from http://www.apsanet.org

Andrews, F. M., \& Robinson, J. P. (1991). Measures of subjective well-being. In J. Robinson, P. Shaver, \& L. Wrightsman (Eds.), Measures of personality and social psychological attitudes. New York: Academic Press.

Astin, A. W. (1993). What matters in college? Four critical years revisited. San Francisco: Jossey-Bass.

Astin, A., \& Sax, L. (1998). How undergraduates are affected by service participation. Journal of College Student Development, 39, 251-263.

Avalos, J., Sax, L. J., \& Astin, A. W. (1999). Long-term effects of volunteerism during the undergraduate years. The Review of Higher Education, 22(2), 187-202.

Baron, R. M., \& Kenny, D. A. (1986). The moderator-mediator variable distinction in social psychological research: Conceptual, strategic, and statistical considerations. Journal of Personality and Social Psychology, 51(6), 1173-1182.

Batchelder, T., \& Root, S. (1994). Effects of an undergraduate program to integrate academic learning and service: Cognitive, prosocial cognitive, and identity outcomes. Journal of Adolescence, 17(4), 341-355.

Bowman, N., Brandenberger, J., Lapsley, D., Hill, P., \& Quaranto, J. (2010). Serving in college, flourishing in adulthood: Does community engagement during the college years predict adult well-being? Applied Psychology: Health and Well-Being, 2(1), 14-34.

Bringing Theory to Practice Project Team, Montclair State University. (n.d.). Bringing Theory to Practice (BTtoP) toolkit instrument: User guide. Retrieved from https://www.aacu.org/bringing theory/documents/Toolkit_InstrumentOverview_UserGuide_2012 000.pdf

Bringle, R. G., \& Steinberg, K. (2010). Educating for informed community involvement. American Journal of Community Psychology, 46, 428-441.

Brower, A. M. (2010). Living-learning programs: One high-impact educational practice we now know a lot about. Liberal Education, 96(2), 36-43.

Brown, B. (Ed.). (2008). Key indicators of child and youth well-being: Completing the picture. New York: Erlbaum.

Busseri, M. A., Rose-Krasnor, L., Mark Pancer, S., Pratt, M. W., Adams, G. R., Birnie Lefcovitch, S., \& Gallander Wintre, M. (2011). A longitudinal study of breadth and intensity of activity involvement and the transition to university. Journal of Research on Adolescence, 21(2), 512518. 
Checkoway, B. (2011). New perspectives on civic engagement and psychosocial well-being. Liberal Education, 97(2), 6-11. Retrieved from http://www.aacu.org/publicationsresearch/periodicals/new-perspectives-civic-engagement-and-psychosocial-well-being

Cohen, J., Cohen, P., West, S. G., \& Aiken, L. S. (2003). Applied multiple regression/correlation analysis for the behavioral sciences ( ${ }^{\text {rd }}$ ed.). Mahwah, NJ: Erlbaum Associates.

Conway, J. M., Amel, E. L., \& Gerwien, D. P. (2009). Teaching and learning in the social context: A meta-analysis of service-learning's effects on academic, personal, social, and citizenship outcomes. Teaching of Psychology, 36(4), 233-245.

Cook, C., Heath, F., \& Thompson, R. L. (2000). A meta-analysis of response rates in web or internetbased surveys. Educational and Psychological Measurement, 60(6), 821-836.

Cranford, J. A., Eisenberg, D., \& Serras, A. M. (2009). Substance use behaviors, mental health problems, and use of mental health services in a probability sample of college students. Addictive Behaviors, 34(2), 134-145.

Degenhardt, L., \& Hall, W. (2001). The relationship between tobacco use, substance-use disorders and mental health: Results from the National Survey of Mental Health and Well-being. Nicotine \& Tobacco Research, 3(3), 225-234.

Eccles, J. S., \& Barber, B. L. (1999). Student council, volunteering, basketball, or marching band what kind of extracurricular involvement matters? Journal of Adolescent Research, 14(1), 10-43.

Eyler, J., \& Giles, D. E. (1999). Where's the service in service-learning? San Francisco: Jossey-Bass.

Fenzel, L. M. (2005). Multivariate analyses of predictors of heavy episodic drinking and drinking-related problems among college students. Journal of College Student Development, 46(2), 126-140.

Finlay, A. K., Ram, N., Maggs, J. L., \& Caldwell, L. L. (2012). Leisure activities, the social weekend, and alcohol use: Evidence from a daily study of first-year college students. Journal of Studies on Alcohol and Drugs, 73(2), 250.

Finn, J., \& Checkoway, B. (1998). Young people as competent community builders. Social Work, 43(4), $335-345$.

Fogal, S. (2004). Risks and opportunities for success: Perceptions of urban youths in a distressed community and lessons for adults. Families in Society, 85(3), 335-344.

Fritz, M. S., \& MacKinnon, D. P. (2007). Required sample size to detect the mediated effect. Psychological Science, 18(3), 233-239.

Furco, A. (1996). Service-learning: A balanced approach to experiential education. Expanding Boundaries: Serving and Learning, 1, 1-6.

Gray, M., Feschwind, S., Ondaatje, R. A., Klein, S., Sax, L., Astin, A., \& Astin, H. (1996). Evaluation of Learn and Serve America: Higher education; first year report (Vol. 1). Los Angeles: Rand Corporation.

Hayes, A. F. (2009). Beyond Baron and Kenny: Statistical mediation analysis in the new millennium. Communication Monographs, 76(4), 408-420.

Honjo, K., Tsutsumi, A., Kawachi, I., \& Nawakami, N. (2006). What accounts for the relationship between social class and smoking cessation? Results of a path analysis. Social Science \& Medicine, 62(2), 317-328.

Hu, L. T., \& Bentler, P. M. (1999). Cutoff criteria for fit indices in covariance structure analysis: Conventional criteria versus new alternatives. Structural Equation Modeling, 6(1), 1-55.

Hurtado, S., \& DeAngelo, L. (2012). Linking diversity and civic-minded practices with student outcomes: New evidence from national surveys. Liberal Education, 98(2), 14-23.

Jones, S. R., \& Hill, K. E. (2003). Understanding patterns of commitment: Student motivation for community service involvement. The Journal of Higher Education, 74(5), 516-539.

Kahne, J. E., \& Sporte, S. E. (2008). Developing citizens: The impact of civic learning opportunities on students' commitment to civic participation. American Educational Research Journal, 45(3), 738-766.

Kelly, D. (2009). In preparation for adulthood: Exploring civic participation and social trust among young minorities. Youth and Society, 40(4), 526-540. 
Keyes, C. L. M. (2002). The mental health continuum: From languishing to flourishing in life. Journal of Health and Social Behavior, 43(2), 207-222.

Keyes, C.L.M. (2006a). Mental health in adolescence: Is America's youth flourishing. American Journal of Orthopsychiatry, 73(3), 395-402.

Keyes, C.L.M. (2006b). The subjective well-being of America' youth: Toward a comprehensive assessment. Adolescent and Family Health, 4(1), 3-17.

Keyes, C. L. M. (2009). Atlanta: Brief description of the mental health continuum short form (MHC-SF). Retrieved from http://calmhsa.org/wp-content/uploads/2013/06/MHC-SFEnglish.pdf

Keyes, C. L. M., \& Haidt, J. (2003). Flourishing: Positive psychology and the life well-lived. Washington, D.C.: American Psychological Association.

Keyes, C. L. M, \& Magyar-Moe, J. L. (2003). The measurement and utility of adult subjective well-being. In S. Lopez, \& C. Snyder (Eds.), Positive psychological assessment: A handbook of models and measures (pp. 411-425). Washington, DC: American Psychological Association.

Kline, R. B. (2011). Principles and practice of structural equation modeling ( $3^{\text {rd }}$ ed.). New York: Guilford Press.

Knapp, T., Fisher, B., \& Levesque-Bristol, C. (2010). Service-learning's impact on college students' commitment to future civic engagement, self-efficacy, and social empowerment. Journal of Community Practice, 18(2-3), 233-251.

Lazarus, R. S., \& Folkman, S. (1984). Stress, appraisal, and coping. New York: Springer.

Lerner, R. (2004). Liberty: Thriving and engagement among America's youth. Thousand Oaks, CA: Sage Publications.

Low, K. (2011). Flourishing, substance use, and engagement in students entering college: A preliminary study. Journal of American College Health, 59(6), 555-561.

MacKinnon, D. P., Fairchild, A. J., \& Fritz, M. S. (2007). Mediation analysis. Annual Review of Psychology, 58, 593-614.

Maddocka, J., Laforgeb, R., Rossib, J., \& O'Hare, T. (2001). The college alcohol problems scale. Addictive Behaviors, 26(3), 385-398

Mathieu, J. E., \& Taylor, S. R. (2006). Clarifying conditions and decision points for mediational type inferences in organizational behavior. Journal of Organizational Behavior, 27(8), 1031-1056.

McCabe, S., Teter, C., \& Boyd, C. (2006). Medical use, illicit use, and diversion of abusable prescription drugs. Journal of American College Health, 54(5), 269-278.

McIntosh, H., Hart, D., \& Youniss, J. (2007). The influence of family political discussion on youth civic development: Which parent qualities matter? PSOnline, 3, 495-499. doi:10.1017/S1049096507070758

Michelsen, E., Zaff, J., \& Hair, E. (2002). Civic engagement programs and youth development: A synthesis. Washington, DC: Child Trends.

Mindrila, D. (2010). Maximum likelihood (ML) and diagonally weighted least squares (DWLS) estimation procedures: A comparison of estimation bias with ordinal and multivariate non-normal data. International Journal of Digital Society, 1(1), 60-66.

Ottenritter, N. (2004). Service-learning, social justice and campus health. Journal of American College Health, 52(4), 189-192.

Penedo, F. J., \& Dahn, J. R. (2005). Exercise and well-being: A review of mental and physical health benefits associated with physical activity. Current Opinion in Psychiatry, 18(2), 189-193.

Reed, V. A., Christian Jernstedt, G., Hawley, J. K., Reber, E. S., \& DuBois, C. A. (2005). Effects of a small-scale, very short-term service-learning experience on college students. Journal of Adolescence, 28(3), 359-368.

Roberts, J. (2013, November). Service learning as a prevention strategy for alcohol use among adolescents. Paper presented at the 141st Annual Meeting of the American Public Health Association, Boston, MA. Retrieved from https://apha.confex.com/apha/141am/webprogram/Paper276415.html

Sigmon, R. (1979). Service-learning: Three principles. Synergist, 8(1), 9-11. 
Silverman, M. (2009, October). Campus student suicides: Crisis and opportunity. Workshop presented at the Provost's Conference on Undergraduate Well-Being, University of Denver, Denver, CO.

Sinclair, M., O’Toole, J., Malawaraarachchi, M., \& Leder, K. (2012). Comparison of response rates and cost-effectiveness for a community-based survey: Postal, internet and telephone modes with generic or personalized recruitment approaches. BMC Medical Research Methodology, 12(1), 132.

Solberg, V., O’Brien, K., Villareal, P., Kennel, P., \& Davis, B. (1993) Self-efficacy and Hispanic students: Validation of the college self-efficacy instrument. Hispanic Journal of Behavioral Sciences, 15(1), 80-95.

Swaner, L. (2007). Linking engaged learning, student mental health and well-being, and civic development: A review of the literature. Liberal Education, 93(1), 16-25.

Terry, A. W., \& Bohnenberger, J. E. (2004). Blueprint for incorporating service-learning: A basic, developmental, K-12 service-learning typology. Journal of Experiential Education, 27(1), 15-31.

Vogelgesang, L., \& Astin, A. W. (2000). Comparing the effects of community service and servicelearning. Michigan Journal of Community Service Learning, 7(1), 25-34.

Vogelgesang, L., Ikeda, E., Gilmartin, S., \& Keup, J. (2002). Service-learning and the first-year experience: Outcomes related to learning and persistence. In E. Zlotkowski (Ed.), Service-learning and the first-year experience: Preparing students for personal success and civic responsibility. The first-year experience monograph series No. 34 (pp. 15-26). National Resource Center for the First-Year Experience ${ }^{\circledR} \&$ Students in Transition, University of South Carolina. Retrieved from http://files.eric.ed.gov/fulltext/ED471259.pdf\#page=30

Weiler, L., Haddock, S., Zimmerman, T. S., Krafchick, J., Henry, K., \& Rudisill, S. (2013). Benefits derived by college students from mentoring at-risk youth in a service-learning course. American Journal of Community Psychology, 52(3-4), 236-248.

Yorio, P. L., \& Ye, F. (2012). A meta-analysis on the effects of service-learning on the social, personal, and cognitive outcomes of learning. Academy of Management Learning \& Education, 11(1), 927.

Zaff, J. F., Malanchuk, O., \& Eccles, J. S. (2008). Predicting positive citizenship from adolescence to young adulthood: The effects of a civic context. Applied Development Science, 12(1), 38-53. 